\title{
Firm Characteristics and Voluntary Segments Disclosure among the Largest Firms in Nigeria
}

\author{
Kabir Ibrahim
}

\begin{abstract}
The aim of this study is to gain more insights in the disclosure practices among the largest public listed companies in Nigeria, by examining the associations between firm characteristics and the extent of voluntary segments disclosure on IFRS 8 Operating Segments by using a sample of 76 companies. The results document that firm size and industry type have positive association with voluntary segments disclosure. In addition, negative association is observed between firm listing age, growth, return on investment, ownership diffusion and voluntary segments disclosure.
\end{abstract}

Index Terms-Firm characteristics, IFRS 8, voluntary disclosure.

\section{INTRODUCTION}

Announcement for the requirement to adopt IFRS in Nigeria was released in September 2010. This is a decision made by the federal executive council of Nigeria in an effort to establish nationwide commitment toward its convergence policy with International Financial Reporting Standards (IFRS) as a basis for financial reporting in Nigeria, effective for fiscal periods beginning after December 31, 2011. The transition process began in 2012 and scheduled to be completed by 2014. Therefore all Nigerian public listed companies are mandated to comply with the provision of IFRS by year 2014. Prior to 2012 Nigerian companies are reporting based on national standards, Statement of Accounting Standards (SAS) issued by Nigerian Accounting Standards Board (NASB) now Financial Reporting Council of Nigeria (FRCN). However, convergence to IFRS in Nigeria indicates that financial institutions that were mandated to adopt IFRS in 2010 faced many difficulties in the convergence process. Reference [1] argued that financial reporting in the pre-IFRS period remained weak compare to advanced jurisdictions, [2] as a result of many inadequacies such as lack of effectiveness and inefficiency in the capital market. Reference [3] study corporate governance attributes towards voluntary segments disclosure in Nigeria and found no association between such mechanisms except in separation of board leadership. It is claimed that implementing of IFRS in Nigeria will face challenges such as the development of legal and regulatory framework [4]. This is despite the fact that accounting principles require authoritative support as well as enforcement measures towards its application in order to meet it's objectives. The objective of preparation and disseminating financial

Manuscript received March 18, 2014; revised May 30, 2014.

Kabir Ibrahim is with the Department of Accounting, Federal Polytechnic Bali, Nigeria (e-mail: kabirne3@gmail.com). information is to provide users of such information with relevant and reliable information in making investment decision. Therefore voluntary disclosure is an interesting topic particularly on segment disclosures for investors and other users as there remain unanswered questions regarding what motivates or influences managers to disclose information.

The objective of this study is to examine empirically the relationship between various firm characteristics and the level of voluntary disclosure on IFRS 8 (operating segments) in the pre-IFRS adoption period (2011) among the largest public listed firms in Nigeria.

\section{LITERATURE REVIEW AND HYPOTHESIS DEVELOPMENT}

Under the structure of "management approach" discretion is given to Chief Operating Decision Maker (CODM) in deciding how to allocate resources and in assessing performance for internal decision purpose [5]. Therefore, decision through management approach is expected to result in yielding quality financial information to capital market as segment reporting provides "decomposition" of a firm's financial statements which have become more informative thus seen as an avenue of providing useful information to analyst and other financial information users [6]. Consequently, segment information will serve as a channel that will maintain investors' confidence in the capital market. Despite the importance of disclosing segment information through management approach, typically Nigeria has given virtually no attention in this area.

IFRS 8 is introduced to provide relevant source of information for the users of financial statement to allow them to have a clear understanding of the concept and overall performance of a company's operations. The principle behind it is to enable users to interpret company's financial position and performance based on internal reports that are regularly reviewed by the CODM. Therefore, adopting management approach will improve financial reporting process in disaggregating more information which allows users of financial statement to review operations through the eyes of management [7]. Consequently, entities are required to disclose segment reporting which is in line with how managers views the entities based on it's internal report [8]. In Jordan [8] investigates the implementation of IFRS 8 on a sample of 109 Jordanian listed companies using checklist of collected information, and shows that there is an increase in the number of companies publishing segmental information under IFRS 8 than IAS 14.Previous scientific studies have touched on the areas of voluntary segment reporting specific to firm characteristic [9]. Attributes such as firm size, company listing age, ownership diffusion, 
return on investment, industry type, and profitability are found to be significantly associated with voluntary disclosure thus these variables will be tested to determine the voluntary segment disclosure in the Nigerian corporate atmosphere.

Age of the company has been identified in previous studies as an attribute having impact on the quality of accounting practice. However company age has been often seen as a proxy for risk [10]. Therefore the extent of firm's voluntary disclosure can be related to how many years it has been in operation [11]. Albeit, the older the firm the more likely they are to have strong internal control procedures. Thus the following hypothesis is developed:

H1: There is positive association between firm age and the extent of voluntary segment disclosure in Nigeria.

Return on Investment (ROI) has also been used in multiple prior studies such as [12]. Reference [13] found a significant positive association between profitability and the level of corporate disclosures. Furthermore, [14] documented that managers tend to willingly report positive news (returns) than negative one because of the effect such news could have on the share price and other indicators. In Italy, [9] confirmed that proprietary costs are particularly relevant and limits the incentive for firms to voluntary disclose segment information to the market. Based on these arguments the following hypothesis is developed.

H2: There is association between profitability and the extent of segment reporting in Nigeria.

Empirical evidence on ownership diffusion has been examined in [15] who found a significant positive relation with disclosure, whereas [12] found a significant negative relation. However, [9] explicates that companies with dispersed shares have a larger number of shareholders who are indirectly involved in managing the affairs of the company, and as a result the agency cost is higher due to information asymmetry between the principal and agent. Therefore disclosing segregated information under management approach is expected to mitigate this problem. Thus this relationship will be tested in the Nigerian context to determine the level of voluntary disclosure as regards to ownership diffusion and therefore a hypothesis is developed:

H3: There is association between diffusion of ownership and the extent of voluntary disclosure of information.

Most empirical studies support the notion that firm size influences corporate disclosure in the like of [16]. Reference [17] finds a significant positive relationship between voluntary disclosure and firm size, measured as the natural logarithm of total asset. References [18], [19] asserted that company size might have a substantial effect on the level of disclosure. Specifically, these aforementioned researches have reported that huge corporations have incentives of disclosing more segmental information. Based on these arguments, the following hypothesis is developed:

H4: There is a positive association between firm size and the extent of company's segment disclosure.

Reference [9] argued that segment reporting may expose the existence of business opportunities to competitors leading to competitive disadvantage to disclosing company and, as a result the extent of voluntary segment disclosure is found to be negatively correlated to the company's growth rate among Italian firms. In contrast [10] posit that high growth firm use voluntary disclosure as a viable means for bridging a potential information gap due to higher information asymmetry between managers and investors. Therefore it is expected in this study that managers may tend to disclose more segment information in order to mitigate information asymmetry.

H5: There is positive association between firm's growth and the extent of voluntary segment disclosure in Nigeria.

The connection between industry-type and disclosure as determinant of corporate disclosure has been examined in previous empirical studies, but they show mixed results. Nevertheless [20] find a significant relationship between disclosure and industry type. In contrast [21], [22] posit that company position has no effect on disclosure. Furthermore, [23] found negative association between industry type and disclosure in Spain. The reputation and credibility of particular industry may indulge companies to adopt disclosing more detailed information than mandated disclosure [23]. Based on this last hypothesis of the study is developed.

H6: There is relationship between the industry type and the extent of company's segment disclosure.

\section{RESEARCH METHODOLOGY}

\section{A. Disclosure Index}

Disclosure index was used on a quantitative basis to measure the extent of segment disclosure in the sample companies' annual reports using the un-weighted index. Disclosure index enables the calculation of total disclosure score for each company under study. Items are identified and measured by counting the total number of items each company disclosed divided by the total items in the study disclosure check list. The sample firms' financial statements are then assessed relative to the list, a score of one is given for each item disclosed and zero is assigned for each non disclosed item. Each firm's aggregate score is then divided by the total number of items relevant to that firm [24].

The disclosure index was constructed based on previous studies [24], [25] as a satisfactory model for financial disclosure and has been used in many studies therefore can be regarded as a reliable model. Descriptive analysis, Pearson correlations as well as Multivariate regression are also employed in this study to explain the patterns derived from each of the 76 annual reports under study and the relationships between the variables of interest.

\section{B. Sample and Data}

The sample of the study was selected among top 100 publicly listed companies by market capitalization out of the total population of 205 companies from all industrial sectors listed on Nigerian Stock Exchange website (NSE) as at 2011. The NSE features 12 sectors: Agriculture, Construction/Real estate, Consumer goods, Financial services, Healthcare, Industrial goods, ICT, Natural resources, Oil and gas, Services, Utilities and Conglomerates [26]. These top 100 listed companies by market capitalization in the country are chosen as they tend to be more visible, accessible and are expected to voluntary disclose more segregated information in their annual reports. References [27], [28] suggested that larger firms disclose more information than the small companies. There are 
chances as company grows in size it will operate in bigger segment environment both business and geographical

\section{Sample Selection}

During the data collection some annual reports are not readily available in NSE or Security and Exchange Commission (SEC) library, their websites or on other financial websites, are therefore removed from the sample (20 in total).Four companies that are reporting based on single line of business are also removed (4) giving a final sample of 76 companies considered in running the relevant analysis.

\section{Regression Model}

The dependent variable in this study is the extent of segment reporting, as measured by the items a company disclosed in their 2011 annual reports. An index based on the number of operating segment items expected to be reported is considered using un-weighted method. Under IFRS 8 requirement, items are only disclosed if they are included in the measures of segment profit/loss and assets or are regularly reported to CODM. The disclosure level is constructed based on this checklist of items potentially disclosed under the requirements of IFRS 8 by performing a content analysis on the annual reports of each company where items are identified and measured. Independent variables examined in this study are return on investment (ROI), company listing age status (AGE), company growth (GRO), firm size (FSIZE), industry type (INDTYPE) and ownership diffusion (DIFF). These are the most tested variables [9].A multivariate regression model is used to test the relationship between the independent and dependent variables.

The data is computed using ordinary least squares regression which is similar to the approach of previous literature as seen in research methodology. The regression model for this study is based on the models from prior studies. Description and measurement of variables in the model are therefore described in Table I.

TABLE I: DESCRIPTION AND MEASUREMENT OF VARIABLES INCLUDED IN THE REGRESSION MODEL

\begin{tabular}{|c|c|c|c|c|}
\hline & VARIABLES & PREDICTION & $\begin{array}{l}\text { PROXY } \\
\text { CODE }\end{array}$ & SIGN \\
\hline 1 & Voluntary disclosure & $\begin{array}{l}\text { Measured as an index that indicates the level of company's } \\
\text { voluntary compliance. }\end{array}$ & VDSCL & \\
\hline 2 & Listing status age & Natural logarithm of the number of years since listed on NSE. & AGE & + \\
\hline 3 & Return on investment & Operating income to total assets. & ROI & $+/-$ \\
\hline 4 & Ownership diffusion & $\begin{array}{l}\text { percentage of shares of less than } 5 \% \text { for share capital owned } \\
\text { by shareholders. }\end{array}$ & DIFF & $+/-$ \\
\hline 5 & Firm size & Measured using natural logarithm of total assets. & FSIZE & + \\
\hline 6 & Growth rate & Measured by ratio of market value to book value of equity. & GRO & + \\
\hline 7 & Industry type & $\begin{array}{l}\text { Measured as dichotomous if financial company is given } 1 \text {, } \\
\text { non financial scored as } 0\end{array}$ & INDTYPE & + \\
\hline
\end{tabular}

\section{RESULTS}

The mean VDSCL of the sampled firms is $43 \%$ and standard deviation is $23 \%$ as seen in Table II and shows that the extent of voluntary disclosure among the sample companies is $43 \%$, which can be considered as moderate.

Preliminary analysis using Pearson correlations as shown in Table III suggests that there is no significant association between the dependent variable (VDSCL) and some independent variables (ROI and GRO), thus providing no support for (H2 and H5).However AGE and DIFF has negative significant correlation of -0.267 and -0.128 with VDSCL. Furthermore, FSIZE and INDTYPE are found significantly correlate at 0.365 and 0.492 respectively. Further analysis with regressions will confirm the results for the tests of the hypotheses.

TABLE II: DESCRIPTIVE STATISTICS

\begin{tabular}{lcccc}
\hline \hline Variables & Mean & Std Dev & Min & Max \\
\hline VDSCL & .4337 & .23319 & .2 & .94 \\
AGE & 2.6213 & 1.10139 & -.37 & 4.09 \\
ROI & 14.7652 & 15.34203 & -19.05 & 67.00 \\
DIFF & 25.7862 & 17.87056 & .83 & 80.93 \\
FSIZE & 24.1027 & 2.14092 & 20.22 & 28.67 \\
GRO & 29.6354 & 22.38720 & 1.05 & 83.68 \\
INDTYPE & .2632 & .44327 & .00 & 1.00 \\
& & & & \\
\hline \hline
\end{tabular}

TABLE III: PEARSON CORRELATION MATRIX

\begin{tabular}{|c|c|c|c|c|c|c|c|}
\hline VARIABL & VDSCL & AGE & ROI & DIFF & FSIZE & GRO & INDTYP \\
\hline VDSCL & 1 & & & & & & \\
\hline $\mathrm{AGE}$ & $-.267^{*}$ & 1 & & & & & \\
\hline ROI & .058 & .197 & 1 & & & & \\
\hline DIFF & -.128 & .066 & .077 & 1 & & & \\
\hline FSIZE & $.365 * *$ & .105 & $.555 * *$ & .049 & 1 & & \\
\hline GROWTH & .066 & .062 & $.360 * *$ & .175 & $.378 * *$ & 1 & \\
\hline INDTYPE & $.492 * *$ & $.318 *$ & $.489 * *$ & .116 & $.466 * *$ & .198 & 1 \\
\hline
\end{tabular}

***Correlation is significant at the 0.01 level (2-tailed)

*Correlation is significant at the 0.05 level (2-tailed). 


\section{Regression Analysis}

Multivariate regression was conducted to investigate the association between the level of voluntary disclosure and firms characteristics. The results of the analysis are presented in Table IV. For H1, a positive significance association between the listing age and the extent of company's segment disclosure was assumed. In Table IV it can be seen that for $\mathrm{H} 1$, the coefficient $\beta_{1}$ for the variable AGE is -267 ( $\mathrm{t}$-value $=-.751$ ), thus providing no support for $\mathrm{H} 1$. This is however, in consistent with the findings of [29] who have not found any significant relationship between age of the firm and the level of corporate disclosure

$\mathrm{H} 2$ hypothesized association between return on investment (ROI) and voluntary segment disclosure (VDSCL). The result shows that the coefficient $\beta_{2}$ is .058 (tvalue $=-2.790)$. Surprisingly the direction shows strong negative relationship and therefore $\mathrm{H} 2$ is not supported. Furthermore, relationship between DIFF and VDSCL is also hypothesized and tested as indicated in H3.A negative association between the two variables is also observed the coefficient $\beta_{3}$ is -.128 ( $\mathrm{t}$-value $=-1.762$ ), therefore providing no evidence to support H3. This corresponds with [12] who found a significant negative relation between ownership diffusion and voluntary disclosure.

Equation:

$\mathrm{VDISCL}=\beta \mathrm{O}+\beta_{1} \mathrm{AGE}+\beta_{2} \mathrm{ROI}+\beta_{3} \mathrm{DIFF}+\beta_{4} \mathrm{FSIZE}+\beta_{5} \mathrm{INDTYPE}+$ $\beta_{6} \mathrm{GRO}+\varepsilon_{0}$

TABLE IV: REGRESSION ANALYSIS BASED ON ORDINARY LEAST SQUARE (OLS)

\begin{tabular}{lll}
\hline \hline Variables & Estimated Coefficient & $\mathrm{t}-$ Value \\
\hline AGE & -.082 & -.751 \\
ROI & -.352 & $-2.790 * * *$ \\
DIFF & -.170 & $-1.765 * *$ \\
FSIZE & .346 & $2.830 * * *$ \\
GROWTH & -.002 & -.016 \\
INDTYPE & .497 & $3.868 * * *$ \\
\hline \hline
\end{tabular}

$N=76$

ADJ $R^{2}=0.341$

$\mathrm{Sig}=.00$

$* * *$ Significance at $1 \%$ level

$* *$ Significance at $5 \%$ level

However, the correlation between FSIZE and VDSCL is positive, significant at $.365^{* *}(\mathrm{t}$-value. $=2.830)$ which means that there is a positive significant association between firm size and the level of operating segment disclosure by the public-listed Nigerian firms thus H4 is supported. This suggests that larger companies have lower incentive to withhold segment information and is similar to the outcomes of previous researchers such as [30]. Furthermore H5 predicts a positive association between company's growth (GRO) and voluntary segment disclosure (VDSCL). The result shows that the coefficient $\beta_{5}$ is $.066(\mathrm{t}$-value $=-.016)$ and the correlation between the two variables is also not significant thus H5 is not supported. Finally based on the findings the result shows that the coefficient $\beta 6$ for the variable INDTYPE and VDSCL is $\beta_{6} .424$ ( $\mathrm{t}$-value =-3.868), supporting $\mathrm{H} 6$ which predicts a positive relationship between industry type and the level of voluntary segment disclosure. This is similar with the findings of [20] who find industry type to be a significant factor contributing the variance in the companies' compliance levels.

\section{CONCLUSION}

The study documents that firm size and industry type influence voluntary segment disclosure. Suggesting, these are the variables motivating management to voluntary disclosed segments information in Nigeria. Descriptive result indicates that the level of voluntary disclosure is $43 \%$ which is an indication that there is tendency for firms to disclose more segments information in the post adoption period through increase reliability of amounts reported in the company's annual reports. Moreover, an indication of negative significant association with (DIFF) means that as large proportion of companies' equity is widespread among shareholders there is separation between ownership and management among Nigerian largest companies. This is likely to be an indication of information asymmetry. Furthermore the identification of negative significant association with (ROI) in the study is an indication that firm with lower profitability tend to voluntary disclosed more segment information than companies with higher profitability in Nigeria. Future research may be conducted by increasing the number of firms examined to make it more generalized and by adding more variables to increase the strength of evidence beyond that presented in this study.

\section{ACKNOWLEDGMENT}

I gratefully acknowledge the financial support provided by Federal Polytechnic Bali in conducting the research. Special thanks go to Dr. Hartini Ja'afar of Department of Accounting and Finance, University Pendidikan Sultan Idris, Malaysia for her wonderful supervision and courage.

\section{REFERENCES}

[1] I. Baba, "Corporate governance and financial Reporting," International Journal of Governance, vol. 1, 2011.

[2] G. Ofoegbu and E. Okoye, "The relevance of accounting and auditing standards in corporate financial reporting in Nigeria: Emphasis on compliance," The Nigerian Accountant, vol. 39, pp. 45-53, 2006.

[3] K. Ibrahim and H. Ja'afar, "Corporate governance and disclosure on segment reporting: Evidence from Nigeria," in Proc. Global Business and Finance Research conf., Taifei, 2013, pp. 1-19.

[4] A. Madawaki, "Adoption of international financial reporting standards (IFRS) in developing countries. The case of Nigeria," International Journal of Business and Management, vol. 7, pp. 152161, 2012.

[5] B. J. Epstein and E. K. Jermakowicz, "IFRS converges to U.S. GAAP on segment reporting," Journal of Accountancy, vol. 207, pp. 50-50, 2009.

[6] European Commission, "Endorsement of IFRS 8operating segments: Analysis of potential effects-reports," Brussel, pp. 4-43, September 3, 2007.

[7] G. Schneider and A. Scholze, "Segment disclosure under the management approach: The impact of proprietary Costs on internal reporting decisions," Discussion Paper Series in Economics and Management, vol. 11-24, pp. 1-17, 2011.

[8] G. H. Mardini, L. Crawford, and D. M. Power, "The impact of IFRS 8 on disclosure practices of Jordanian listed companies," Journal of Accounting in Emerging Economics, vol. 2, pp. 67-90, 2012.

[9] A. Prencipe, "Proprietary cost and determinant of voluntary segment disclosure: Evidence from Italian listed companies," European Accounting Review, vol. 13, pp. 319-340, 2004.

[10] F. Cerbioni and Perbonetti, "Exploring the effects of corporate governance on intellectual capital disclosure: An analysis of European 
biotechnology companies," Journal of European Accounting Review, vol. 16, pp. 791-826, 2007.

[11] J. R. Graham, C. R. Harvey, and S. Rajgopal, "The economic implications of corporate financial reporting," Journal of Accounting and Economics, vol. 40, pp. 33-73, 2005.

[12] N. S. Zourarakis, Voluntary Disclosure: Evidence from UK, Eramus University Rotterdam Digital Repository, 2009, pp. 83-108.

[13] P. Mahajan and S. Chanders, "Corporate disclosure practices in India software industry: An empirical study," Journal of Accounting Research, vol. 6, pp. 43-70, 2007.

[14] S. Sehgal, L. Bhalla, and M. Bhalla, "Corporaate disclosure practices: An empirical study," The Journal of Accounting Reseach, vol. 5, pp. $38-52,2006$.

[15] X. Huafang and Y. Jianguo, "Ownership structure, board composition and corporate voluntary disclosure: Evidence from listed companies in China," Managerial Auditing Journal, vol. 22, pp. 604-619, 2007.

[16] D. G. Barako, "Factors influencing voluntary corporate disclosure by Kenyan companies," Corporate Governance: An International Review, vol. 14, pp. 107-125, 2006.

[17] I. Adelopo, "Voluntary disclosure practices amongst listed companies in Nigeria," Advances in Accounting, Incorporating Advances in International Accounting, vol. 27, pp. 338-345, 2011

[18] M. Talha, A. Sallehhuddin, and J. Mohammad, "Changing pattern of competitive disadvantage from disclosing financial information: A case study of segmental reporting practice in Malaysia," Managerial Auditing Journal, vol. 2, pp. 265-274, 2006.

[19] M. Suwaidan, A. Omari, and S. Abed, "The segmental information disclosures in the annual reports of the Jordanian industrial companies: A filed study," Commercial College for Scientific Research: Alexandria University, vol. 2, pp. 1-48, 2007.

[20] K. Ahmed and J. K. Courtis, "Associations between corporate characteristics and disclosure levels in annual reports: A metaanalysis," The British Accounting Review, vol. 31, pp. 35-61, 1999.

[21] S. Owusu-Ansah, "The impact of corporate attributes onthe extent of mandatory disclosure and reporting by listed companies in Zimbabwe," The International Journal of Accounting, vol. 33, pp. 605-631, 1998

[22] M. Akhtaruddin, "Corporate mandatory disclosure practices in Bangladesh," International Journal of Accounting, vol. 40, pp. 399$422,2005$.
[23] R. S. O. Wallace, K. Naser, and A. Mora, "The relationship between comprehensiveness of corporate annual reports and firm characteristics in Spain," Journal of Accounting and Business Research, vol. 25, pp. 41-53, 1994.

[24] R. M. Haniffa and T. E. Cooke, "Culture, corporate governance and disclosure in Malaysian corporations," Journal of Accounting and Public Policy, vol. 12, pp. 31-44, 2002.

[25] R. S. O. Wallace, "Corporate financial reporting in Nigeria," Accounting and Business Research, vol. 18, pp. 352-362, 1988.

[26] Nigerian Stock Exchange. Companies listed by marketcapitalization. 2012. NSE website. [Online]. Available: http//www.nse.ng.org

[27] N. Aripin, G. Tower, and G. Taylor, "The determinants financial ratio disclosures and quality: Australian evidence. Accounting and finance association of Australia and New Zealand (AFAANZ)," in Proc. Annual Conference Sydney, Australia, July 2008, pp. 6-8.

[28] P. Brammer and S. Pavelin, "Voluntary environmental disclosures by large UKcompanies," Journal of Business Finance and Accounting, vol. 33, pp. 1168-1188, 2006.

[29] G. A. Despina and S. Antonios, "The association between the firm characteristics and corporate mandatory disclosure the case of Greece," World Academy of Science, Engineering and Technology, vol. 77, pp. 101-107, 2011

[30] Leuz, "Proprietary vs non-proprietary disclosure: Voluntary cash-flow statement and business segment reporting in Germany," Working Paper Department of Business Economics, Johann Wolfgang GoetheUniversitat, Frankfurt, no. 21, pp. 1-46, March 1999.

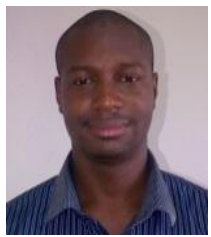

Kabir Ibrahim has completed his master degree in the field of financial accounting from University Pendidikan Sultan Idris, Malaysia. Mr. Kabir Ibrahim is currently a lecturer at the Federal Polytechnic Bali, Nigeria and his research interest includes financial reporting and corporate governance. 